か?

答

山下 一也（関西）

日常成書汇ある方法で撮影した場合，必ずしむ正確な 像をえられないし，また，文献を調べてもマチマチであ る.よって実際にはどうなっているかを27例について計 測したものであるが，非常に個人差が大きく共通点がな かった。乙の研究は日本人の基淮值を出す目的ではなく 臨床的に正確な像を求めるための足がかりを調べたすの である。

熊谷 定義（福岡）

\section{9. 内反足撮影法の検討}

信州大学医学部付属病院 中央放射線部

(部長 小林 敏雄 整形外科講師 寺山 和雄) ○市川 吴・丸山 静夫・塚原 芳郎 丸山喜代次·宮林 宏保·安藤 隆 横井 憲明

内反足とは足先と足底が特殊な変化を示し, 距骨に対 し，踵骨，方形骨，舟状骨の変化が基本的因子である. そこで足根骨の相互関係と，X線計測による数量化が是 非共必要なので, 次の 6 種類の撮影方法に入射角度を变 化し検討した。

(1) 背底方向撮影

(2) 側方向

（3）足関節最大背屈

(4) 足関節最大底屈

(5) 垂直軸方向

(6) 後軸方们撮影

以上の結果内反足撮影法として，

(1) $30^{\circ}$ 底屈份の背底方们

(2) $30^{\circ}$ 底屈時側方向

（3） $45^{\circ}$ 後軸撮影の 3 方向を原則としている. また再現性のため簡易に装着できる内反足撮影補助台 を製作し，好結果を得ている。

\section{0. 鼻骨撮影の検討}

鳥取大学医学部付属病院 放射線部 (部長 阿武 保郎教授) 浜田 英吉・松本 宗夫 角彰・角田酽 角原 重利・野々村貴德 山岡 信夫・国岡 孝志

[目的]

鼻骨軸位撮影について検討した。

[方法]

鼻骨側面軟部撮影に対しドイツ水平線を想定した標識 を同時に撮影し，ての $\mathrm{x}$ 線像によりドイツ水平線と鼻尖
と舅翼根を結えだ線のなす角度を求めた結果，われわれ が測定した45例の成人男子の平均は37度であった。 との 角度をもとにして, 㫾翼とフィルム面が平行状態にて， しかも，乙れに垂直に $\mathrm{x}$ 線中心線を入射させることが望 ましいと考光, その結果, 幾何学的にドイツ水平線と $\mathrm{x}$

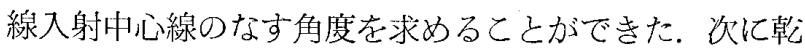
燥した人体頭蓋骨を用いて，その正中線をフィルム面に 垂直汇置き，ドイツ水平線と $\mathrm{x}$ 線入射中心線とのなす角 度を30度から70度变で変位させ撮影し $\mathrm{x}$ 線像の変化を観 察するととむに臨床的にも種々の角度で撮影検討した。 [結果]

ドイツ水平線と $\mathrm{x}$ 線入射中心線のなす角度は50〜 55度 の範用では診断的に有効であるが53度が最適であった。

\section{質問}

短頭, 長頭乙の関係を明確にしなかったら,より正し い角度なり位置なりきめられないと思う，如何でしょ う.

山下 一也 (関西)

\section{答}

現在，軸位撮影はよく行なわれておりますが，はっき りとした撮影体位が私の調べた限りでありませんのでそ の体位を知ろうとするすので欧米人と日本人の問題です が同じ日本人でも男女の別によって舅骨の突出が異なる といわれ，その日本人について検討したもので，欧米人 についても文献等によって調べてみたい.

\section{X線による股関節前捻角直接計測法の研究}

兵厙県立整肢施設のじぎく園

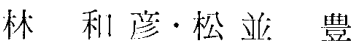

大腿骨頸部前捻角を 1 枚のフィルムで直接計測するに は大腿軸をフィルムに直立させて撮影せね齐ならないの で厚い軟部組識のために適当なコントラストが得られず 困難である，元のため当所では次の方法によって㬰施し ている．被検者を基本肢位より股関節および㯟関節をそ れぞれ $90^{\circ}$ 屈曲した坐位にし軕膝窝部に鋼線を犆き基底 線とし，それを含めて正中線と両股関節を結ぶ線の交点 亿焦点を合わせ撮影する．撮影時の体位は大腿軸がフィ ルムに垂直であるとは限らずまた両側の頸部を同時に撮 影するために各頸部に対してはX線が斜入するためフィ ルム上の角度は，正しい前捻角を示しているとはいえな い. そこでわれわれは数例にわたって実験的に大腿軸の 傾斜角度とX線斜入角度を求为，作図によって補正を行 なった結果実際の角度とフィルム上の角度との差はわず か $3 \%$ 内外にすぎず測定上の許容誤差範团内として補正 をせずにそのまま彰療汇役立てるととが可能であると考 えられる。 